\title{
Significance of the isolation of Clostridium welchii from routine blood cultures
}

\author{
FERIAL J. AHMAD AND J. H. DARRELL \\ From the Department of Bacteriology, Royal Postgraduate Medical School, Hammersmith Hospital, \\ Du Cane Road, London W12 OHS
}

SYNOPSIS Clostridium welchii has been demonstrated in approximately $20 \%$ of contact plates taken from the antecubital fossa of 185 inpatients and outpatients and healthy staff. The highest incidence was in a group of $\mathbf{4 0}$ very ill patients. The isolation of the organism from blood cultures is not always of clinical significance. Skin preparation as at present practised is often inadequate to remove the spores when contamination is relatively heavy, for example, in bedridden patients.

In previous years a proportion of our blood cultures have yielded Clostridium welchii in one only of the three bottles, all of which have been shown to be capable of supporting its growth.

In 1974 the laboratory processed about 3000 blood cultures. In 30 of $\mathbf{7 4 5}$ cultures yielding growth the organism isolated was $\mathrm{Cl}$. welchii. The majority of patients from whom these cultures were taken did not seem to have systemic infection and in no case did bacteraemia with $\mathrm{Cl}$. welchii seem to have had pathological effects.

A possible explanation was that $\mathrm{Cl}$. welchii spores might exist on the skin of the antecubital fossa in the way described by Parker (1969) and Ayliffe and Lowbury (1969) for the skin of the buttock and thigh. In an investigation of a small group of 25 individuals, Collee and Watt (1971) have demonstrated a few colonies of $\mathrm{Cl}$. welchii on swabs taken from the hands and forearms in three by direct plating. This proportion rose to over $50 \%$ of 17 hand swabs after enrichment, as would of course occur in normal blood culture techniques.

\section{Material and Methods}

Nagler medium screened with $100 \mu \mathrm{g} / \mathrm{ml}$ neomycin, as described by Lowbury and Lilly (1955), was used in the form of Contact plates. Colonies growing on this medium and showing lecithinase activity after 18 hours' anaerobic incubation were accepted as presumptive $\mathrm{Cl}$. welchii. Few other organisms grow on this medium.

Presumptive $\mathrm{Cl}$. welchii isolates were subjected to the following confirmatory tests:

Received for publication 3 July 1975
1 Subculture aerobically and anaerobically on blood agar to prove that there were strict anaerobes

2 A half antitoxin plate using $\mathrm{Cl}$. welchii antitoxin and including a known $\mathrm{Cl}$. welchii as a control to demonstrate specific neutralization of lecithinase activity

3 Inoculation of litmus milk to show the 'stormy clot' formation

4 Demonstration of acid production from lactose in a peptone water sugar tube.

The last two tests were done to distinguish $\mathrm{Cl}$. bifermentans, which does not ferment lactose but shows cross neutralization with welchii antitoxin.

\section{SAMPLING METHODS}

The skin of the antecubital fossa of both arms was sampled by the use of surface Contact plates. The skin was then disinfected with $70 \%$ isopropyl alcohol (Medi Swab) using 20 strokes for 30 seconds. The disinfectant was allowed to dry, and sampling was repeated in the same area. Both plates (before and after skin treatment) were incubated anaerobically overnight, examined for presumptive $\mathrm{Cl}$. welchii colonies, and compared to demonstrate the effect of skin preparation.

One hundred inpatients were studied over an eight-week period. A control group of 85 ambulant patients attending the anaemia outpatients and staff members were investigated in a similar way.

\section{Results}

The results of these investigations are shown in tables I to III. 


\begin{tabular}{llll}
\hline Subjects & Total & No. positive & $\%$ \\
\hline Inpatients & 100 & 21 & 21 \\
Outpatients and staff & 85 & 16 & 18 \\
\hline
\end{tabular}

Table I Numbers of $\mathrm{Cl}$. welchii isolated from patients studied

\begin{tabular}{llll}
\hline Inpatients & Total & No. positive & $\%$ \\
\hline Very ill & 40 & 13 & 32 \\
Ill & 38 & 6 & 15 \\
Convalescent & 22 & 3 & 13.6 \\
\hline
\end{tabular}

Table II Cl. welchii isolated from inpatients according to severity of their illness

\begin{tabular}{llllll}
\hline \multirow{2}{*}{ Total Inpatients } & \multicolumn{2}{c}{ Before Skin Preparation } & & \multicolumn{2}{c}{ After Skin Preparation } \\
\cline { 2 - 3 } \cline { 5 - 6 } & No. & Positive $\%$ & & No. & Positive \% \\
\hline 100 & 21 & 21 & & 16 & 16 \\
\hline
\end{tabular}

Table III Effect of skin preparation with isopropyl alcohol

Repeat sampling of nine patients giving positive results and of nine negative patients as a control, after a two-week interval, showed that of nine longstay female orthopaedic patients mainly suffering from fractured neck of the femur, three demonstrated persisting carriage over this period (table IV).

\begin{tabular}{ll}
\hline No. of Patients & No. carrying $\mathrm{Cl}$. welchii after 2 Weeks \\
\hline 9 previously positive & 3 still carrying $\mathrm{Cl}$. welchii \\
9 negative & 1 now carrying $\mathrm{Cl}$. welchii \\
\hline
\end{tabular}

Table IV Persistence of carriage of $\mathrm{Cl}$. welchii over a two-week period

\section{Discussion}

In our study of 100 inpatients, which revealed $21 \%$ antecubital fossa carriage of $\mathrm{Cl}$. welchii, most carriers were elderly women who had been in hospital for a long time, for example, geriatric orthopaedic patients. When lying in bed their arms were in such a position that the antecubital fossa was in contact with the buttock area or the sheets in this area. These patients were heavily contaminated with $\mathrm{Cl}$. welchii spores, ie, more than 100 colonies per plate, and attempts at disinfection had little effect in removing the spores.

Three out of nine carried the organism for a period of more than two weeks. One new carrier previously negative was demonstrated at the end of the period. This may have represented only a sampling error in the original test.

The effectiveness of isopropyl alcohol in removing light contamination (ie, one or two colonies) can be explained as mechanical removal since alcohol is not sporicidal. Compresses of the iodophor, povidoneiodine, applied for 15-30 minutes have been found to be useful by Lowbury et al (1964) and Ayliffe and Lowbury (1969). Washing with soap and water was found to be ineffective by Ayliffe and Lowbury (1969). We did not try these methods because they are not used in skin preparation before sampling blood for culture.

The method of preparing the skin for this purpose was that recommended by Washington (1975). The $\vec{\overrightarrow{ }}$ skin is cleansed with 70-90\% ethyl alcohol followed $\stackrel{\omega}{\omega}$ by an alcoholic solution of iodine (1-20\%). Using this method, $70 \%$ alcohol alone has been found to i decrease the skin microflora by at least $90 \%$ However, it will certainly not kill all the bacteria in the deep layers of the dermis, particularly in structures such as sweat glands and hair follicles 0 (Updegraff, 1964). Alternatively, Washington recommended the use of povidone iodine swab sticks. The $z$ intended site of needle entry should not be touched unless the fingers used for palpation have been simi- $\frac{\rho}{S}$ larly disinfected or gloves are worn. Upon com- $\overrightarrow{0}$ pletion of the venepuncture residual iodine should $\partial$ be removed with an alcohol sponge or pad.

Our tests again illustrate the ineffective nature of much skin preparation before venepuncture, showing that at least when carriage is heavy the perfunctory techniques often employed will not remove clostridial $\frac{\Phi}{\Phi}$ spores. The finding of $\mathrm{Cl}$. welchii in blood cultures $\cong$ is not necessarily of clinical significance, and even $\overrightarrow{\overrightarrow{0}}$ its repeated isolation over a period of weeks may 3 not represent infection in the patient but merely, in some cases, contamination from the site of venepuncture.

Our thanks are due to Mr M. Kreuzer, of Sterilin Limited, for making available the supply of Contact plates used in this study.

\section{References}

Ayliffe, G. A. J. and Lowbury, E. J. L. (1969). Sources of gas

gangrene in hospital. Brit. med. J., 2, 333-337.
Collee, J. G. and Watt, B. (1971). Changing approaches to. the sporing anaerobes in medical microbiology in Spore $N$ Research, 1971, edited by A. N. Barker, G. W. Gould and J. Wolf, p. 39. Academic Press, London and NewW York.

Lowbury, E. J. L. and Lilly, H. A. (1955). A selective plate medium for $\mathrm{Cl}$. welchii. J. Path. Bact., 70, 105-109.

Lowbury, E. J. L., Lilly, H. A., and Bull, J. P. (1964). Methods for disinfection of hands and operation sites. + Brit. med. J., 2, 531-536.

Parker, M. T. (1969). Postoperative clostridial infections in Britain. Brit. med. J., 3, 671-676.

Updegraff, D. M. (1964). A cultural method of quantitatively $\frac{\mathrm{P}}{\mathbb{D}}$ studying the microorganisms in the skin. J. invest. Derm., 43, 129-137.

Washington, J. A., II. (1975). Blood cultures, principles and $\bar{\gamma}$ techniques. Mayo Clin. Proc., 50, 91-98. 